\title{
Workshop
}

\section{The Nitrogen Use Efficiency: Meaning and Sources of Variation-Case Studies on Three Vegetable Crops in Central Italy}

\author{
Paolo Benincasa ${ }^{1}$, Marcello Guiducci, and Francesco Tei
}

ADDITIONAL INDEX WORDs. processing tomato, lettuce, sweet pepper, organic, mineral, fertigation, partitioning

Summary. Nitrogen (N) use efficiency (NUE) of crops is examined by taking into account both plant $\mathrm{N}$ uptake efficiency, focusing on the recovery of fertilizer- $\mathrm{N}$, and the utilization efficiency of the absorbed $\mathrm{N}$. The latter is further analyzed as the overall effect of the absorbed $\mathrm{N}$ on crop leaf area, light absorption, photosynthesis, crop growth, biomass partitioning, and yield. The main sources of variation for the NUE of crops are considered, and several of them are discussed based on results from field experiments carried out at the University of Perugia (central Italy) between 1991 and 2008 on sweet pepper (Capsicum annuum), lettuce (Lactuca sativa), and processing tomato (Solanum lycopersicum). More specifically, the effects of species, cultivar, fertilizer-N rate, form and application method (mineral and organic fertilization, green manuring, fertigation frequency), and sink limitation are reported. Implications for residual $\mathrm{N}$ in the soil and leaching risks are also discussed. The fertilizer-N rate is the main factor affecting crop NUE for a given irrigation management and rainfall regime. Indeed, avoiding over fertilization is the first and primary means to match a high use efficiency and economic return of fertilizer- $\mathrm{N}$ with limited environmental risks from nitrate leaching. The form and application method of fertilizer-N also may affect the NUE, especially in the case of limiting or overabundant $\mathbf{N}$ supply. Particularly, high fertigation frequency increased the recovery of fertilizer- $\mathrm{N}$ by the crop. It is suggested that species-specific curves for critical $\mathrm{N}$ concentration (i.e., the minimum $\mathrm{N}$ concentration that allows the maximum growth) can be the reference to calibrate the quick tests used to guide dynamic fertilization management, which is essential to achieve both the optimal crop $\mathbf{N}$ nutritional status and the maximum NUE.

Meaning of nitrogen USE EFFICIENCY. Several studies have addressed the optimization of fertilization and the improvement of NUE of crops to achieve high yields with

Department of Agricultural and Environmental Sciences, University of Perugia, Borgo XX Giugno, 7406121 Perugia, Italy

This paper was part of the workshop "Improvement in Nitrogen and Water Use Efficiency: Interest of Assessment Tools" held 16 Sept. 2008 at the European Society for Agronomy Congress, Bologna, Italy.

${ }^{1}$ Corresponding author. E-mail: paoloben@unipg.it. reduced $\mathrm{N}$ fertilization rates and limited environmental side effects related to $\mathrm{N}$ leaching (Agostini et al., 2010; Burns, 2006; Neeteson and Carton,
2001; Rahn, 2002). However, few experiments have examined NUE in all its aspects. $\mathrm{N}$ use efficiency is the result of two main components: $\mathrm{N}$ uptake efficiency, which is the ability of crops to take up $\mathrm{N}$ from the soil (Burns, 2006; Greenwood et al., 1989), and use efficiency of the absorbed $\mathrm{N}$, that is the efficiency with which crops use the absorbed $\mathrm{N}$ to grow and give yield (Janssen, 1998; Schenk, 2006). These efficiencies may differ within the same crop because they depend on different organs and mechanisms and on different environmental factors as well.

Burns (2006) examined the crop $\mathrm{N}$ uptake efficiency in detail, concluding that the crop $\mathrm{N}$ uptake from the soil $\left(U_{\mathrm{N}}\right)$ is a function of two recovery factors, one for the fertilizer- $\mathrm{N}$ and one for the soil- $\mathrm{N}$, as follows:

$$
U_{\mathrm{N}}=f_{\mathrm{F}} \times N_{\mathrm{F}}+f_{\mathrm{S}} \times N_{\mathrm{S}},
$$

where $N_{\mathrm{F}}=\mathrm{N}$ available from the fertilizer (kilograms per hectare); $f_{\mathrm{F}}=$ recovery factor for $N_{\mathrm{F}} ; N_{\mathrm{S}}=\mathrm{N}$ available from the soil (kilograms per hectare) (i.e., soil mineral $\mathrm{N}$ at crop establishment), $\mathrm{N}$ from soil organic matter (SOM), and $\mathrm{N}$ from crop residues; and $f_{S}=$ recovery factor for $N_{S}$.

The two recovery factors are required because soil- $\mathrm{N}$ and fertilizer- $\mathrm{N}$ may be differently available in time and space. However, the author concluded that in most cases the two recovery factors can be considered nearly equivalent; therefore, the uptake efficiency of fertilizer- $\mathrm{N}$ [i.e., the apparent $\mathrm{N}$ recovery (REC)] can be estimated on the basis of the $\mathrm{N}$ uptake of the unfertilized control as proposed by Greenwood et al. (1989):

$$
\mathrm{REC}=f_{\mathrm{F}}=\left(U_{\mathrm{F}}-U_{0}\right) / \mathrm{N}_{\mathrm{F}},
$$

where $N_{\mathrm{F}}=$ fertilizer- $\mathrm{N}$ rate (kilograms per hectare), $U_{\mathrm{F}}=\mathrm{N}$ uptake (kilograms per hectare) when $N_{\mathrm{F}}$ is given, and $U_{0}=\mathrm{N}$ uptake (kilograms per hectare) in nonfertilized plots.

\begin{tabular}{llll}
\hline $\begin{array}{l}\text { Units } \\
\begin{array}{l}\text { To convert U.S. to SI, } \\
\text { multiply by }\end{array}\end{array}$ & U.S. unit & SI unit & $\begin{array}{l}\text { To convert SI to U.S., } \\
\text { multiply by }\end{array}$ \\
\hline 2.54 & inch $(\mathrm{es})$ & $\mathrm{cm}$ & 0.3937 \\
1.1209 & $\mathrm{lb} / \mathrm{acre}$ & $\mathrm{kg} \cdot \mathrm{ha}^{-1}$ & 0.8922 \\
305.1517 & $\mathrm{oz} / \mathrm{ft}^{2}$ & $\mathrm{~g} \cdot \mathrm{m}^{-2}$ & 0.0033 \\
1 & $\mathrm{ppm}$ & $\mathrm{mg} \cdot \mathrm{L}^{-1}$ & 1 \\
2.0 & ton $(\mathrm{s}) / \mathrm{lb}$ & $\mathrm{Mg} \cdot \mathrm{kg}^{-1}$ & 0.5
\end{tabular}


Alternatively, to assess the two recovery factors separately, ${ }^{15} \mathrm{~N}$-labeled fertilizers can be used (Nason and Myrold, 1991; Petersen et al., 2004), but this technique is not often available to researchers. Instead, the REC as proposed by Greenwood et al. (1989) can be easily calculated from published data.

The use efficiency of absorbed $\mathrm{N}\left(\mathrm{N}_{\mathrm{a}} \mathrm{UE}\right)$ should be calculated by considering the total crop dry weight (DW) accumulated per kilogram of absorbed N. However, roots are often neglected and only the shoot biomass is taken into account. The $\mathrm{N}_{\mathrm{a}} \mathrm{UE}$ is affected by all the mechanisms involved in plant growth, like the effect of $\mathrm{N}$ on crop leaf area, light absorption, and photosynthesis, at both ecophysiological and cellular levels (Tei et al., 2000, 2002b), by assuming absence of other limiting factors. Much research has been carried out on these aspects, but it is seldom possible to derive useful information from literature on the relationship between ecophysiological parameters and crop NUE.

Moreover, in cultivated crops, the $\mathrm{N}_{\mathrm{a}} \mathrm{UE}$ is often based on the sole marketable DW yield or marketable fresh weight yield (MFWY) per kilogram of absorbed N. This problem is even more complex in vegetables for which the potential yield can be much different from the actual marketable yield (MY) because only part of the yield is of sufficient quality to be commercialized (Van Eerd, 2007). Finally, sometimes the NUE has been reported in terms of harvest index on a DW basis and N (Schenk, 2006). Hence, the terminology is rather confusing (Janssen, 1998) and the information available in literature on this subject cannot be easily used or compared.
SOURCES OF VARIATION FOR N USE EFFICIENCY. Species and cultivars are expected to play a primary role: the genotype affects both the $\mathrm{N}$ uptake and the use of absorbed $\mathrm{N}$ because every genotype has its own morphological and functional characteristics for roots, leaves, etc. (Schenk, 2006; Thorup-Kristensen and Sørensen, 1999; Thorup-Kristensen and Van der Boogard, 1999). However, the same genotype can show different NUEs when subjected to different levels of $\mathrm{N}$ availability (e.g., in general, crops are more efficient at recovering $\mathrm{N}$ when the fertilizer- $\mathrm{N}$ rate is relatively low) (Burns, 2006). Present efforts of breeding, screening programs, or both for improving the NUE of cultivars (e.g., through improved initial root growth rate, maximum root expansion, root/shoot $\mathrm{DW}$, and $\mathrm{N}$ partitioning) at either limiting or nonlimiting $\mathrm{N}$ availability seem worth to be improved to reduce fertilizer supplies (Good et al., 2004; Hirel et al., 2007; Schenk, 2006).

Environmental factors (temperature, rainfall, soil texture, etc.) can affect the NUE as they affect either crop growth and development or the $\mathrm{N}$ availability from the soil through effects on mineralization of SOM and organic fertilizers and on nitrate leaching (Agostini et al., 2010). For this reason, any conclusions regarding NUE of crops should derive from experiments carried out in different years and localities. For the same reason, detailed climate and soil conditions should be reported in studies dealing with crop NUE.

An important role is played by crop management (Neeteson et al., 1999). This includes crop density and spatial arrangement of plants (Shapiro and Wortmann, 2006), $\mathrm{N}$ fertilization rate and application methods (for both placement and timing) ( $\mathrm{Li}, 2003$; Linaje et al., 2005; Ma and Kalb, 2006; Osborne, 2006), water management, and concurrent management of fertilizer and water by fertigation (Battilani et al., 2003; Remie et al., 2003; Singandhupe et al., 2003). The recent use of microorganisms and plant growth promoters would be worth evaluating for their effects on NUE (Chen et al., 2003; Gadagi et al., 2004). Finally, the source-sink relationships as modified by crop management and environmental factors, including abiotic and biotic stresses, may alter biomass and $\mathrm{N}$ partitioning and hence the $\mathrm{N}_{\mathrm{a}} \mathrm{UE}$ when calculated on a part of the whole plant (Vouillot and DevienneBarret, 1999; Yong-Zhan et al., 1996; Zvomuya and Rosen, 2002).

Most of the above aspects have been studied in detail, but the effects on the efficiency of both $\mathrm{N}$ uptake and use of absorbed $\mathrm{N}$ cannot always be derived from reported data. In this work, published and unpublished data from several field trials on $\mathrm{N}$ nutrition of vegetable crops carried out at the University of Perugia from 1991 to 2008 will be analyzed to examine the NUE and some of the factors that can affect it.

\section{Case studies on three vegetable crops in central Italy}

The effect of $\mathrm{N}$ rate, species, and cultivar on the $\mathrm{N}$ uptake of sweet pepper, tomato, and lettuce has been investigated by Tei et al. (1999). The authors found that, in all species, increasing $\mathrm{N}$ rate increased the shoot $\mathrm{N}$ accumulation but linearly decreased the REC (Fig. 1), as observed in other vegetables (Greenwood et al., 1989). The REC was low in
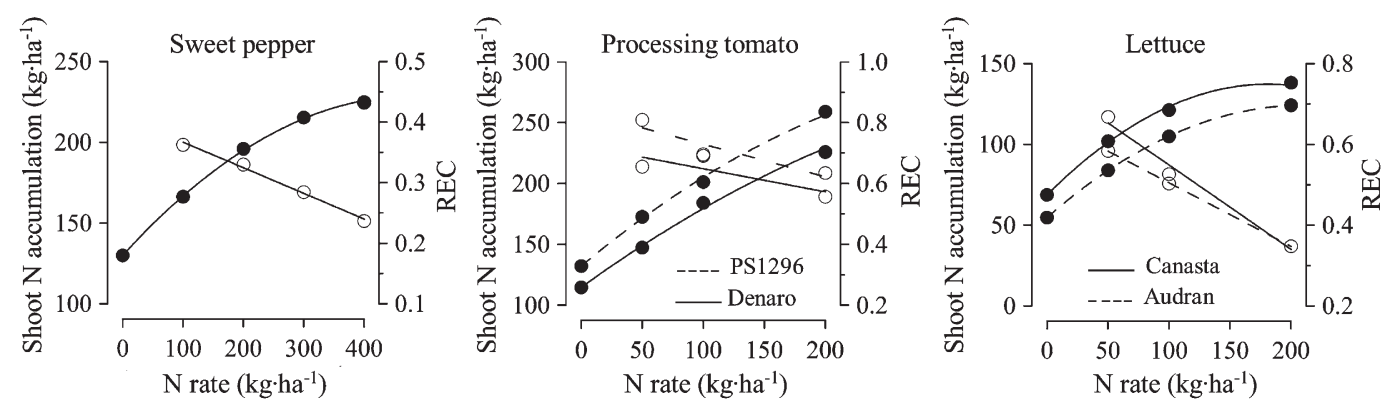

Fig. 1. Shoot nitrogen (N) accumulation and apparent recovery of fertilizer-N (REC) as affected by fertilizer-N rate in 'Heldor' sweet pepper, 'Denaro' and 'PS1296' processing tomato, and 'Audran' and 'Canasta' lettuce (from Tei et al., 1999, modified); $1 \mathrm{~kg} \cdot \mathrm{ha}^{-1}=0.8922 \mathrm{lb} /$ acre . 
sweet pepper and high in processing tomato, whereas in lettuce it was high at low $\mathrm{N}$ rates but then decreased with increasing $\mathrm{N}$ rates. The two cultivars tested in both processing tomato and lettuce had different REC at low N rate, but the differences decreased with increasing $\mathrm{N}$ rate (Fig. 1). This was to be expected because with a high $\mathrm{N}$ availability other factors, besides the ability of the cultivar to take up $\mathrm{N}$, become prevalent.

Since the $\mathrm{N}$ availability required to obtain the maximum MY was different for the three considered crops (highest in sweet pepper, intermediate in processing tomato, and lowest in lettuce), sweet pepper left a considerable amount of mineral $\mathrm{N}$ in the soil at harvest, whereas processing tomato left minimum amount of mineral $\mathrm{N}$ (Tei et al., 1999).

Tei et al. (1999) did not further examine the aspect of the $\mathrm{N}_{\mathrm{a}} \mathrm{UE}$. On the basis of maximum MFWY and the correspondent $\mathrm{N}$ accumulation, the $\mathrm{N}_{\mathrm{a}} \mathrm{UE}$ was higher in lettuce, followed by processing tomato and then by sweet pepper (Table 1). However, on a shoot DW basis, (i.e., the more correct method of calculating $\mathrm{N}_{\mathrm{a}} \mathrm{UE}$ ), the most efficient would be tomato and the least lettuce, with little differences between cultivars (Table 1 ).

To obtain useful information on the mechanisms that govern the $\mathrm{N}_{\mathrm{a}} \mathrm{UE}$, in fruit vegetable crops it should be split in two components, one related to building the canopy and one related to fruit production, where the first component is a prerequisite to the second one (Tei et al., 1996). Moreover, the effect of $\mathrm{N}$ fertilization rate on the crop leaf area and light absorption should be evaluated, as this is the driving force for crop photosynthesis and growth. Tei et al. (2002a) reported an increase of crop leaf area in processing tomato at increasing $\mathrm{N}$ availabilities and found a linear relationship between the amount of absorbed $\mathrm{N}$ and light absorption (Fig. 2). They also found that leaves at high $\mathrm{N}$ availability had a slightly higher photosynthetic activity at high irradiance levels as compared with leaves from $\mathrm{N}$-deficient plants. The overall result is that biomass accumulation increases with plant $\mathrm{N}$ content. A linear relationship was found between the plant $\mathrm{N}$ content and the relative growth rate (RGR) of processing tomato, and the

Table 1. Fertilizer-nitrogen $(\mathrm{N})$ rate required to obtain the maximum $(\max )$ marketable yield (MY) in the experiments reported by Tei et al. (1999) on sweet pepper, lettuce and processing tomato, and correspondent values for shoot $\mathrm{N}$ accumulation, apparent recovery of fertilizer-N (REC), and use efficiency of absorbed $\mathrm{N}\left(\mathrm{N}_{\mathrm{a}} \mathrm{UE}\right)$ calculated on the basis of either shoot dry weight (DW) or marketable fresh weight yield (MFWY) (derived from Tei et al., 1999 and unpublished data).

\begin{tabular}{|c|c|c|c|c|c|c|}
\hline Species & Cultivar & $\begin{array}{l}\text { N rate for } \\
\max M Y \\
\left(\mathrm{~kg} \cdot \mathrm{ha}^{-1}\right)^{\mathrm{z}}\end{array}$ & $\begin{array}{c}\text { Shoot } \mathrm{N} \\
\text { accumulation } \\
\left(\mathrm{kg} \cdot \mathrm{ha}^{-1}\right)\end{array}$ & $\begin{array}{c}\text { REC } \\
(\%)\end{array}$ & $\begin{array}{l}\mathrm{N}_{\mathrm{a}} \mathrm{UE} \text { on } \\
\text { shoot DW } \\
\left(\mathrm{Mg} \cdot \mathrm{kg}^{-1}\right)^{\mathrm{z}}\end{array}$ & $\begin{array}{c}\mathrm{N}_{\mathrm{a}} \mathrm{UE} \text { on } \\
\mathrm{MFWY} \\
\left(\mathrm{Mg} \cdot \mathrm{kg}^{-1}\right)\end{array}$ \\
\hline Sweet pepper & Heldor & 309 & 216 & 28 & 0.038 & 0.18 \\
\hline \multirow[t]{2}{*}{ Tomato } & Denaro & 200 & 226 & 57 & 0.046 & 0.46 \\
\hline & PS1296 & 200 & 259 & 62 & 0.042 & 0.45 \\
\hline \multirow[t]{2}{*}{ Lettuce } & Canasta & 158 & 136 & 43 & 0.029 & 0.69 \\
\hline & Audran & 167 & 121 & 39 & 0.027 & 0.60 \\
\hline
\end{tabular}

${ }^{\mathrm{z}} \mathrm{l} \mathrm{kg} \cdot \mathrm{ha}^{-1}=0.8922 \mathrm{lb} / \mathrm{acre}, \mathrm{l} \mathrm{Mg} \cdot \mathrm{kg}^{-1}=0.5$ ton $/ \mathrm{lb}$.

relationship was even stronger if the ratio between leaf $\mathrm{N}$ and plant $\mathrm{N}$ was taken into consideration (Tei et al., 2002b) (Fig. 3) because leaves are the metabolic compartment mainly primarily implicated in plant growth (Caloin and $\mathrm{Yu}, 1984$ ). Similar evidences were found in sweet pepper (Tei et al., 1996).

Greenwood et al. (1990) developed the concept of critical N, which is the minimum $\mathrm{N}$ concentration in the plant required for its maximum growth, and Lemaire and Gastal (1997) proposed the critical $\mathrm{N}$ dilution curve, since critical $\mathrm{N}$ concentration decreases with an increasing biomass accumulation during the growth cycle. Hence, at any time of the growth cycle there is a critical $\mathrm{N}$ concentration below which the plant shows a limited growth and above which the plant shows a luxury consumption (Greenwood et al., 1990; Lemaire and Gastal, 1997). Lettuce gives a classical example of luxury consumption. In fact, the RGR may be not strictly related to the absorbed $\mathrm{N}$ when calculated on a DW basis, but a strong relationship has been found on FW basis (Tei et al., 2000). This occurs because lettuce tends to accumulate a high amount of absorbed $\mathrm{N}$ in the vacuoles as nitrate- $\mathrm{N}\left(\mathrm{NO}_{3}-\mathrm{N}\right)$, which is not involved in growth processes (Maynard et al., 1976). What is important for a lettuce grower, however, is the MFWY; therefore, data expressed on parameters other than MFWY are misleading.

Critical $\mathrm{N}$ dilution curves are species-specific. Tei et al. (2002a, 2003) calculated the curves for both total $\mathrm{N}$ and reduced $\mathrm{N}$ for either processing tomato or lettuce. Critical curves

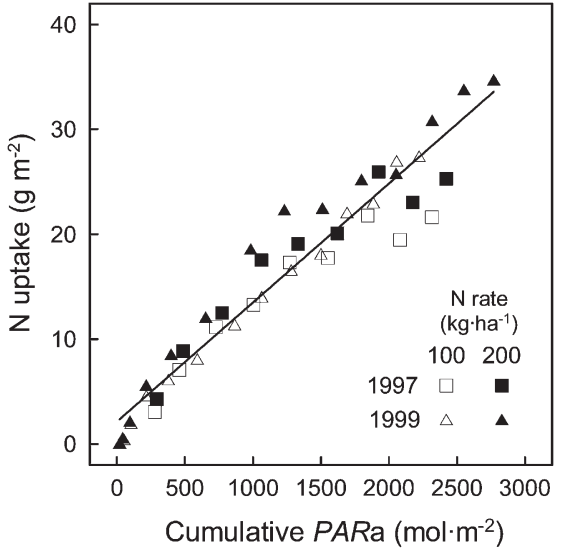

Fig. 2. Relationship between shoot nitrogen $(\mathrm{N})$ accumulation and cumulative absorption of $P A R$ ( $P A R$ a) in processing tomato grown in 2 years (1997 and 1999) at the two fertilizer-N rates of 100 and $200 \mathrm{~kg} \cdot \mathrm{ha}^{-1} \mathrm{~N}$ (Tei et al., 2002b); $1 \mathrm{~kg} \cdot \mathrm{ha}^{-1}=0.8922 \mathrm{lb} /$ acre, $1 \mathrm{~g} \cdot \mathrm{m}^{-2}=0.0033 \mathrm{oz} / \mathrm{ft}^{2}$.

should be the reference to evaluate the nutritional $\mathrm{N}$ status of any crop in any situation and to calibrate quick tests, like chlorophyll meter readings (Gianquinto et al., 2003) and measurements of $\mathrm{NO}_{3}-\mathrm{N}$ concentration in petiole sap (Jimenez et al., 2006), for dynamic in-season and in-field adjustment of $\mathrm{N}$ fertilization (Battilani et al., 2003; Farneselli et al., 2010; Lemaire, 2007; Tremblay and Belec, 2005).

Increasing $\mathrm{N}$ availability causes an increase in shoot DW and $\mathrm{N}$ accumulation, and MY, but the increase is not linear at high $\mathrm{N}$ rates (Tei et al., 2002a). As a consequence, the $\mathrm{N}_{\mathrm{a}} \mathrm{UE}$ tends to decrease, especially for $\mathrm{N}$ rates higher than the rate required to achieve a critical $\mathrm{N}$ concentration (Table 2).

Generally, the N fertilization rate has little or no effect on biomass and 


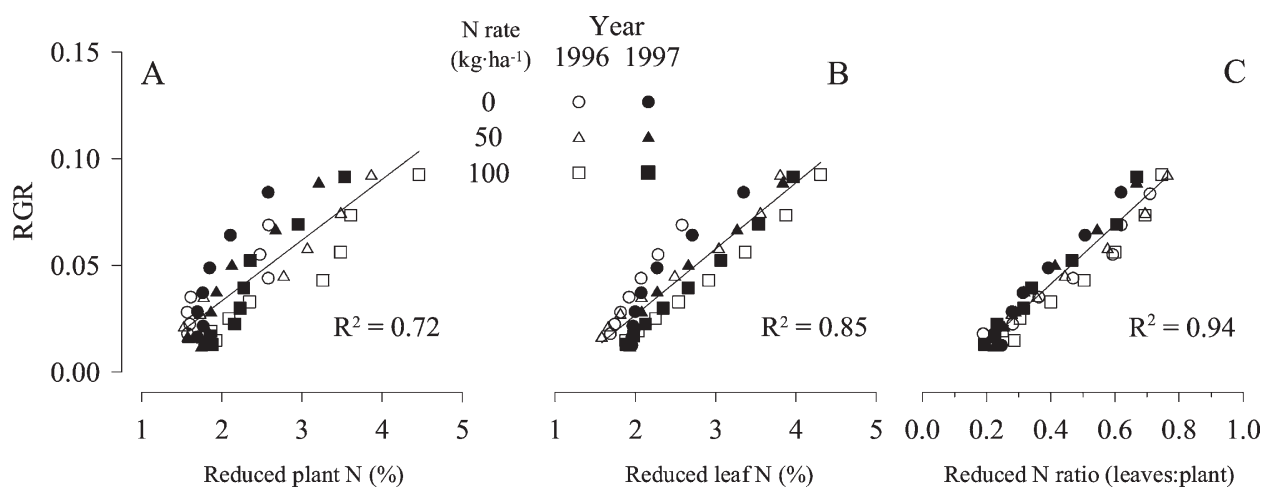

Fig. 3. Relationships between relative growth rate (RGR) and (A) shoot reduced-nitrogen (N) content, (B) leaf reduced-N content, and (C) leaf to shoot reduced-N ratio in processing tomato grown in 2 years (1997 and 1999) at three fertilizer- $\mathrm{N}$ rates: 0,50 , and $100 \mathrm{~kg} \cdot \mathrm{ha}^{-1} \mathrm{~N}$ (Tei et al., 2002b); $1 \mathrm{~kg} \cdot \mathrm{ha}^{-1}=0.8922 \mathrm{lb} /$ acre.

Table 2. Effect of fertilizer-nitrogen $(\mathrm{N})$ rate on shoot $\mathrm{N}$ accumulation and on the use efficiency of absorbed $\mathrm{N}\left(\mathrm{N}_{\mathrm{a}} \mathrm{UE}\right)$ calculated for processing tomato on the basis of either shoot dry weight (DW), or total fruit dry weight, or marketable fresh weight yield (MFWY) in 3 years (derived from Tei et al., 2002b).

\begin{tabular}{|c|c|c|c|c|c|}
\hline$\underline{\text { Yr }}$ & $\begin{array}{c}\mathrm{N} \text { rate } \\
\left(\mathrm{kg} \cdot \mathrm{ha}^{-1}\right)^{\mathrm{z}}\end{array}$ & $\begin{array}{c}\text { Shoot } \mathrm{N} \\
\text { accumulation } \\
{\left[\text { mean } \pm \mathrm{SE}\left(\mathrm{kg} \cdot \mathrm{ha}^{-1}\right)\right]}\end{array}$ & \multicolumn{3}{|c|}{$\mathrm{N}_{\mathrm{a}} \mathrm{UE}\left[\text { mean } \pm \text { SE }\left(\mathrm{Mg} \cdot \mathrm{kg}^{-1}\right)\right]^{\mathrm{z}}$} \\
\hline \multirow[t]{3}{*}{1996} & 0 & $110 \pm 5.2$ & $0.057 \pm 0.0005$ & $0.038 \pm 0.0026$ & $0.54 \pm 0.009$ \\
\hline & 100 & $178 \pm 13.5$ & $0.054 \pm 0.0001$ & $0.033 \pm 0.0013$ & $0.47 \pm 0.001$ \\
\hline & 200 & $233 \pm 11.9$ & $0.042 \pm 0.0001$ & $0.026 \pm 0.0004$ & $0.44 \pm 0.011$ \\
\hline & 100 & $229 \pm 24.0$ & $0.048 \pm 0.0023$ & $0.034 \pm 0.0010$ & $0.55 \pm 0.010$ \\
\hline & 200 & $288 \pm 27.9$ & $0.043 \pm 0.0040$ & $0.031 \pm 0.0024$ & $0.46 \pm 0.035$ \\
\hline \multirow[t]{4}{*}{1999} & 0 & $203 \pm 5.8$ & $0.048 \pm 0.0011$ & $0.030 \pm 0.0005$ & $0.43 \pm 0.025$ \\
\hline & 50 & $209 \pm 6.1$ & $0.053 \pm 0.0019$ & $0.033 \pm 0.0015$ & $0.54 \pm 0.030$ \\
\hline & 100 & $275 \pm 12.4$ & $0.048 \pm 0.0004$ & $0.031 \pm 0.0012$ & $0.51 \pm 0.034$ \\
\hline & 200 & $347 \pm 10.9$ & $0.042 \pm 0.0019$ & $0.027 \pm 0.0009$ & $0.45 \pm 0.011$ \\
\hline
\end{tabular}

${ }^{\mathrm{z}} 1 \mathrm{~kg} \cdot \mathrm{ha}^{-1}=0.8922 \mathrm{lb} / \mathrm{acre}, \mathrm{l} \mathrm{Mg} \cdot \mathrm{kg}^{-1}=0.5 \mathrm{ton} / \mathrm{lb}$.

$\mathrm{N}$ partitioning; therefore, the harvest indices for biomass and $\mathrm{N}$ are little or not at all affected (Tei et al., 2002b). However, with very high $\mathrm{N}$ rates there can be an increase of non-MY as it has been often observed in processing tomato (Tei et al., 2002a), and as a consequence the $\mathrm{N}_{\mathrm{a}} \mathrm{UE}$ calculated on an MY basis can decrease (Table 2). A similar behavior also was found in the case of limiting $\mathrm{N}$ availability (Nendel et al., 2009; Rather and Schenk, 2005).

The fertilizer- $\mathrm{N}$ form and application methods as a possible source of variation for the NUE can be examined by analyzing data from a series of field experiments on green manuring or organic vs. mineral fertilization and on the fertigation frequency of processing tomato.

The fertilization of processing tomato by green manures has been studied during a 3-year experiment, and some of the results were reported by Tosti (2008), Tosti et al. (2008), and Farneselli et al. (2009). The authors evaluated green manures of pure stands or mixtures of hairy vetch (Vicia villosa) and barley (Hordeum vulgare) with various proportions of the two species as defined by seed rates at sowing and then compared them to an unfertilized control and mineral fertilized controls (urea at 100 and $\left.200 \mathrm{~kg} \cdot \mathrm{ha}^{-1} \mathrm{~N}\right)$. Table 3 shows unpublished data from the 2006 trial, where the $\mathrm{N}_{\mathrm{a}} \mathrm{UE}$ for tomato was quite constant and very high in the case of green manures, regardless of the $\mathrm{N}$ supply, whereas it decreased considerably with an increasing mineral $\mathrm{N}$ fertilization rate. This was probably related to the pattern of $\mathrm{N}$ release in the soil (Benincasa et al., 2004, 2008; Boldrini et al.,
2007). Table 3 does not show any parameter concerning the $\mathrm{N}$ uptake efficiency because the comparison between green manure $\mathrm{N}$ and mineral fertilizer- $\mathrm{N}$ is not immediately understandable and can lead to misinterpretations. In fact, the green manure pre-emptive competition (i.e., the depletion of soil mineral $\mathrm{N}$ due to green manure $\mathrm{N}$ uptake) should be taken into account (Thorup-Kristensen et al., 2003 ). This competition is variable depending on soil texture and the amount of winter rainfall: that is because $\mathrm{N}$ leaching decreases at high soil clay content and low winter rainfall. The soil- $\mathrm{N}$ absorbed by green manures is beneficial because it is preserved from leaching (Macdonald et al., 2005). In fact, Farneselli et al. (2009) found that all green manure crops listed in Table 3 , especially those with barley, reduced the $\mathrm{NO}_{3}-\mathrm{N}$ concentration in suction 
lysimeter cups located at a depth of 90 $\mathrm{cm}$. However, in many cases additional $\mathrm{N}$ supply from the soil and organic manures that have been applied in preceding years may alter the picture and as a consequence studies on NUE can be incomplete (Fink and Scharpf, 2000; Guo et al., 2010).

Reduced negative side effects of fertilization are generally expected from the use of organic fertilizers; however, the supposed benefits cannot be taken for granted. Rather, both conventional and organic fertilization efficiencies depend on the adoption of suitable $\mathrm{N}$ fertilization rate strategies. As an example, in a field experiment on processing tomato grown in a clay-loam soil with $1.3 \%$ SOM and drip irrigated once per week, Benincasa et al. (2007) compared localized mineral $\mathrm{N}$ fertigation to the organic fertilization with poultry manure broadcast at transplanting. As expected, there was a clear effect of $\mathrm{N}$ rate, but no appreciable effect of the fertilizer- $\mathrm{N}$ form and distribution methods on either the $\mathrm{N}$ accumulation and the residual $\mathrm{N}$ in the soil or the shoot DW and MY so that in the end the NUE was unaffected (Table 4 ).

Further sources of variation on REC or $\mathrm{N}_{\mathrm{a}} \mathrm{UE}$ may be brought about by variants within the same fertilization method (Home et al., 2002). Farneselli (2008) compared three weekly fertigation-irrigation frequencies at the same water volume per week as follows: one fertigation (or one irrigation in the unfertilized control), one fertigation plus two irrigations, and three fertigations (or three irrigations in the unfertilized control). The author demonstrated that at the fertilization rate of $300 \mathrm{~kg} \cdot \mathrm{ha}^{-1}$ $\mathrm{N}$, which is close to what is often used by growers, the REC increased with an increasing fertigation frequency, although the $\mathrm{N}_{\mathrm{a}} \mathrm{UE}$ was slightly decreased (Table 5). Indeed, in that experiment the petiole sap $\mathrm{NO}_{3}-\mathrm{N}$ concentration was much higher, likely too high, with a high fertigation frequency, which implies that some luxury consumption of $\mathrm{N}$ occurred at $300 \mathrm{~kg} \cdot \mathrm{ha}^{-1} \mathrm{~N}$ (Fig. 4) (Farneselli et al., 2010). Fertigation-irrigation frequency was hypothesized to affect the $\mathrm{N}$ uptake as a result of the shape of the wetted soil volume, the spatial distribution of roots, the soil moisture and nutrient concentration in the rhizosphere between irrigations, and thus the uptake pattern and rates of water and nutrients (Farneselli, 2008).

Finally, unpublished data for tomato $\mathrm{N}$ uptake from the experiment described by Benincasa et al. (2006) show how the NUE can be affected by altered source-sink relationships. In a 3-year open-field experiment on processing tomato, the authors compared an untreated control to a sinklimited treatment where all the flowers

Table 3. Nitrogen (N) supply to the soil, shoot $\mathrm{N}$ accumulation, and use efficiency of absorbed $\mathrm{N}\left(\mathrm{N}_{\mathrm{a}} \mathrm{UE}\right)$ calculated on the basis of either shoot dry weight (DW) or marketable fresh weight yield (MFWY) in processing tomato fertilized by green manuring and urea at the rate of 100 and $200 \mathrm{~kg} \cdot \mathrm{ha} \mathrm{a}^{-1} \mathrm{~N}$ or not fertilized. The two green manure species (hairy vetch and barley) were grown as pure crops ( $\mathrm{V}=$ hairy vetch; $\mathrm{B}=$ barley) or mixed at various proportions (V75/B25, V50/B50, V25/ $\mathrm{B} 75$ ) of the full seed rate used for their respective pure crops (i.e., $200 \mathrm{~kg} \cdot \mathrm{ha}^{-1}$ of seeds for barley and $90 \mathrm{~kg} \cdot \mathrm{ha} \mathrm{h}^{-1}$ for hairy vetch).

\begin{tabular}{|c|c|c|c|c|}
\hline Treatment & $\underset{\left.\left(\mathrm{kg} \cdot \mathrm{ha}^{-1}\right)\right]^{\mathrm{z}}}{\mathrm{N} \text { supply }[\text { mean }} \pm \mathrm{SE}$ & $\begin{array}{c}\text { Tomato shoot } \mathrm{N} \\
\text { accumulation } \\
{\left[\text { mean } \pm \mathrm{SE}\left(\mathrm{kg} \cdot \mathrm{ha}^{-1}\right)\right]}\end{array}$ & $\begin{array}{c}\mathrm{N}_{\mathrm{a}} \mathrm{UE} \text { on shoot DW } \\
{[\text { mean } \pm \mathrm{SE}} \\
\left.\left(\mathrm{Mg} \cdot \mathrm{kg}^{-1}\right)\right]^{\mathrm{z}}\end{array}$ & $\begin{array}{c}\mathrm{N}_{\mathrm{a}} \mathrm{UE} \text { on MFWY } \\
{[\text { mean } \pm \mathrm{SE}} \\
\left.\left(\mathrm{Mg} \cdot \mathrm{kg}^{-1}\right)\right] \\
\end{array}$ \\
\hline $\mathrm{B}$ & $30 \pm 1.9$ & $163 \pm 10.9$ & $0.053 \pm 0.0015$ & $0.57 \pm 0.0081$ \\
\hline $\mathrm{V} 25 / \mathrm{B} 75$ & $74 \pm 11.3$ & $190 \pm 14.6$ & $0.052 \pm 0.0014$ & $0.57 \pm 0.0307$ \\
\hline $\mathrm{V} 50 / \mathrm{B} 50$ & $95 \pm 9.1$ & $215 \pm 17.6$ & $0.050 \pm 0.0030$ & $0.54 \pm 0.0505$ \\
\hline $\mathrm{V} 75 / \mathrm{B} 25$ & $145 \pm 10.3$ & $219 \pm 13.3$ & $0.050 \pm 0.0012$ & $0.59 \pm 0.0458$ \\
\hline Urea & 100 & $246 \pm 11.9$ & $0.042 \pm 0.0010$ & $0.48 \pm 0.0368$ \\
\hline Urea & 200 & $313 \pm 16.8$ & $0.036 \pm 0.0013$ & $0.41 \pm 0.0060$ \\
\hline
\end{tabular}

${ }^{2} 1 \mathrm{~kg} \cdot \mathrm{ha}^{-1}=0.8922 \mathrm{lb} / \mathrm{acre}, \mathrm{l} \mathrm{Mg} \cdot \mathrm{kg}^{-1}=0.5 \mathrm{ton} / \mathrm{lb}$.

Table 4. Shoot nitrogen (N) accumulation, apparent recovery of fertilizer-N (REC), and use efficiency of absorbed $N\left(N_{a} U E\right)$ calculated on the basis of either shoot dry weight (DW) or marketable fresh weight yield (MFWY) for processing tomato not fertilized (CONTROL) or fertilized at different $\mathrm{N}$ rates by localized mineral fertigation (FIRR) or broadcast organic fertilization (ORG) (derived from Benincasa et al., 2007).

\begin{tabular}{|c|c|c|c|c|c|}
\hline \multirow[b]{2}{*}{$\begin{array}{c}\text { Fertilization } \\
\text { method }\end{array}$} & \multirow[b]{2}{*}{$\begin{array}{c}\mathrm{N} \text { rate } \\
\left(\mathrm{kg} \cdot \mathrm{ha}^{-1}\right)^{\mathrm{z}}\end{array}$} & \multirow[b]{2}{*}{$\begin{array}{c}\text { Shoot } N \\
\text { accumulation } \\
{\left[\text { mean } \pm \text { SE }\left(\mathrm{kg} \cdot \mathrm{ha}^{-1}\right)\right]}\end{array}$} & \multirow[b]{2}{*}{$\begin{array}{c}\operatorname{REC}[\text { mean } \pm \\
\text { SE (\%)] }\end{array}$} & \multicolumn{2}{|c|}{$\mathbf{N}_{\mathbf{a}} \mathrm{UE}$} \\
\hline & & & & $\begin{array}{c}\text { On shoot DW } \\
{[\text { mean } \pm \text { SE }} \\
\left.\left(\mathrm{Mg} \cdot \mathrm{kg}^{-1}\right)\right]^{\mathrm{z}} \\
\end{array}$ & 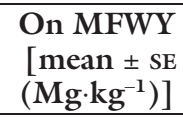 \\
\hline CONTROL & 0 & $135 \pm 7.3$ & - & $0.056 \pm 0.0025$ & $0.43 \pm 0.044$ \\
\hline \multirow[t]{2}{*}{ FIRR } & 100 & $167 \pm 9.6$ & $32 \pm 18.1$ & $0.057 \pm 0.0052$ & $0.40 \pm 0.031$ \\
\hline & 200 & $176 \pm 14.4$ & $20 \pm 12.8$ & $0.051 \pm 0.0037$ & $0.42 \pm 0.012$ \\
\hline & 200 & $186 \pm 4.4$ & $26 \pm 1.3$ & $0.048 \pm 0.0016$ & $0.38 \pm 0.026$ \\
\hline & 300 & $252 \pm 14.4$ & $39 \pm 12.3$ & $0.042 \pm 0.0008$ & $0.31 \pm 0.032$ \\
\hline
\end{tabular}

${ }^{\mathrm{z}} \mathrm{l} \mathrm{kg} \cdot \mathrm{ha}^{-1}=0.8922 \mathrm{lb} / \mathrm{acre}, \mathrm{l} \mathrm{Mg} \cdot \mathrm{kg}^{-1}=0.5 \mathrm{ton} / \mathrm{lb}$. 
Table 5. Shoot nitrogen (N) accumulation, apparent recovery of fertilizer-N (REC), and use efficiency of absorbed $\mathrm{N}\left(\mathrm{N}_{\mathrm{a}} \mathrm{UE}\right)$ calculated on the basis of either shoot dry weight (DW) or marketable fresh weight yield (MFWY) for processing tomato unfertilized or fertilized at $300 \mathrm{~kg} \cdot \mathrm{ha}^{-1}$ of mineral $\mathrm{N}$ with different weekly fertigation-irrigation frequencies and the same water volume per week: one fertigation ( $1 \mathrm{f}$ ) [or just one irrigation ( $1 \mathrm{i}$ ) for the unfertilized control], one fertigation plus two irrigations ( $1 \mathrm{f}+2 \mathrm{i}$ ), and three fertigations (3 f) [or just three irrigations ( $3 \mathrm{i})$ for the unfertilized control] (derived from Farneselli, 2008).

\begin{tabular}{|c|c|c|c|c|c|}
\hline \multirow{2}{*}{$\begin{array}{l}\mathrm{N} \text { rate } \\
\left(\mathrm{kg} \cdot \mathrm{ha}^{-1}\right)^{\mathrm{z}}\end{array}$} & \multirow{2}{*}{$\begin{array}{l}\text { Fertigation- } \\
\text { irrigation } \\
\text { frequency }\end{array}$} & \multirow{2}{*}{$\begin{array}{c}\text { Shoot } \mathrm{N} \\
\text { accumulation } \\
{\left[\text { mean } \pm \mathrm{SE}\left(\mathrm{kg} \cdot \mathrm{ha}^{-1}\right)\right]}\end{array}$} & \multirow{2}{*}{$\begin{array}{c}\operatorname{REC}[\text { mean } \pm \mathrm{SE} \\
(\%)]\end{array}$} & \multicolumn{2}{|c|}{$\mathrm{N}_{\mathrm{a}} \mathrm{UE}\left[\text { mean } \pm \mathrm{SE}\left(\mathrm{Mg} \cdot \mathrm{kg}^{-1}\right)\right]^{\mathrm{z}}$} \\
\hline & & & & On shoot DW & On MFWY \\
\hline 0 & $3 \mathrm{i}$ & $142 \pm 12.4$ & - & $0.055 \pm 0.0028$ & $0.40 \pm 0.024$ \\
\hline \multirow[t]{2}{*}{300} & $\mathrm{lf}$ & $292 \pm 37.0$ & $51 \pm 12.3$ & $0.037 \pm 0.0011$ & $0.32 \pm 0.029$ \\
\hline & $1 \mathrm{f}+2 \mathrm{i}$ & $334 \pm 29.9$ & $65 \pm 10.0$ & $0.034 \pm 0.0021$ & $0.27 \pm 0.022$ \\
\hline
\end{tabular}

${ }^{\mathrm{z}} 1 \mathrm{~kg} \cdot \mathrm{ha}^{-1}=0.8922 \mathrm{lb} / \mathrm{acre}, \mathrm{l} \mathrm{Mg} \cdot \mathrm{kg}^{-1}=0.5 \mathrm{ton} / \mathrm{lb}$.

were removed except for the proximal one of any inflorescence, so that the fruit number at harvest was $\approx 1 / 3$ to $2 / 3$ lower (depending on the year) than in the untreated control. This simulated the effect of a severe abiotic or biotic stress. The different sink availability was combined with a different source capacity obtained with two levels of $\mathrm{N}$ availability, a limiting (unfertilized control) and a nonlimiting one (mineral fertilization of $400 \mathrm{~kg} \cdot \mathrm{ha}^{-1} \mathrm{~N}$ ). Table 6 reports data from one of the 3 years. The sink availability did not affect the shoot DW and $\mathrm{N}$ accumulation at both $\mathrm{N}$ availabilities and the REC of the fertilized treatment. On the contrary, both the biomass and the $\mathrm{N}$ partitioning were heavily affected, with a greater partitioning into vegetative parts for the sink-limited treatment (Benincasa et al., 2006). Hence, the $\mathrm{N}_{\mathrm{a}} \mathrm{UE}$ calculated on a shoot DW basis was substantially unaffected, whereas there was a marked effect on $\mathrm{N}_{\mathrm{a}} \mathrm{UE}$ calculated on the MFWY (Table 6).

\section{Conclusions}

The NUE of crops should be investigated in all its aspects, and scientists should make an attempt to report data that allow the reader to obtain complete information and to compare results. The NUE is affected by several factors, but in most cases, for a given irrigation management and rainfall regime, the fertilizer- $\mathrm{N}$ rate is the main source of variation, especially with regard to the $\mathrm{N}$ uptake issue. Indeed, avoiding overfertilization is the first and main means to match a high use efficiency and economic return of fertilizer-N with limited environmental risks from nitrate leaching. The fertilizer- $\mathrm{N}$ form and application method also may affect the

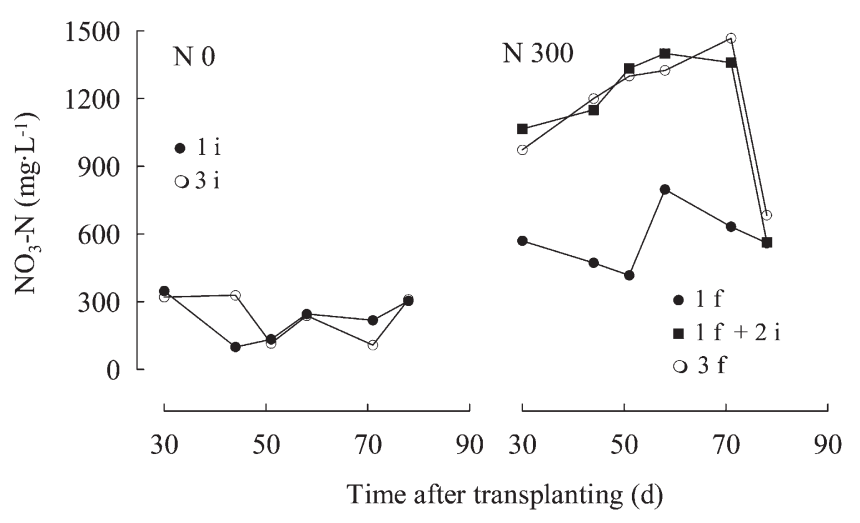

Fig. 4. Petiole sap nitrate- $\mathrm{N}\left(\mathrm{NO}_{3}-\mathrm{N}\right)$ concentration in leaves of processing tomato unfertilized (N0) or fertilized at $300 \mathrm{~kg} \cdot \mathrm{ha}^{-1}$ of mineral N (N 300) with different weekly fertigation-irrigation frequencies and the same water volume per week: one fertigation ( $1 \mathrm{f}$ ) [or just one irrigation ( $1 \mathrm{i}$ ) for N0], one fertigation plus two irrigations ( $1 \mathrm{f}+2 \mathrm{i}$ ), and three fertigations $(3 \mathrm{f})$ [or just three irrigations $(3 \mathrm{i})$ for N0]. Sed $=285.4$ (from Farneselli et al., 2010 , modified); $1 \mathrm{~kg} \cdot \mathrm{ha}^{-1}=0.8922 \mathrm{lb} /$ acre, $1 \mathrm{mg} \cdot \mathrm{L}^{-1}=1 \mathrm{ppm}$.

Table 6. Shoot nitrogen $(\mathrm{N})$ accumulation, apparent recovery of fertilizer- $\mathrm{N}$ (REC), and use efficiency absorbed $\mathrm{N}\left(\mathrm{N}_{\mathrm{a}} \mathrm{UE}\right)$ calculated on the basis of either shoot dry weight (DW) or marketable fresh weight yield (MFWY) for processing tomato grown in 1999 with limiting or non limiting $\mathbf{N}$ availability (i.e., unfertilized or fertilized with $400 \mathrm{~kg} \cdot \mathrm{ha}^{-1} \mathrm{~N}$ as urea) and with normal or reduced sink availability imposed by partial removal of the flowers (derived from Benincasa et al., 2006 and unpublished data).

\begin{tabular}{|c|c|c|c|c|c|}
\hline \multirow{2}{*}{$\begin{array}{l}\mathrm{N} \text { rate } \\
\left(\mathrm{kg} \cdot \mathrm{ha}^{-1}\right)^{\mathrm{z}}\end{array}$} & \multirow[b]{2}{*}{ Sinks } & \multirow{2}{*}{$\begin{array}{c}\text { Shoot } \mathrm{N} \\
\text { accumulation } \\
{[\text { mean } \pm \text { SE }} \\
\left.\left(\mathrm{kg} \cdot \mathrm{ha}^{-1}\right)\right]\end{array}$} & \multirow{2}{*}{$\begin{array}{c}\text { REC } \\
{[\text { mean } \pm} \\
\text { SE }(\%)]\end{array}$} & \multicolumn{2}{|c|}{$\mathrm{N}_{\mathrm{a}} \mathrm{UE}\left[\text { mean } \pm \text { SE }\left(\mathrm{Mg} \cdot \mathrm{kg}^{-1}\right)\right]^{\mathrm{z}}$} \\
\hline & & & & On shoot DW & On MFWY \\
\hline \multirow[t]{2}{*}{0} & Normal & $194 \pm 11.2$ & - & $0.049 \pm 0.0012$ & $0.40 \pm 0.024$ \\
\hline & Reduced & $190 \pm 10.1$ & - & $0.052 \pm 0.0018$ & $0.26 \pm 0.099$ \\
\hline \multirow[t]{2}{*}{400} & Normal & $456 \pm 41.7$ & $66 \pm 0.5$ & $0.032 \pm 0.0018$ & $0.28 \pm 0.025$ \\
\hline & Reduced & $463 \pm 43.1$ & $68 \pm 1.9$ & $0.029 \pm 0.0002$ & $0.11 \pm 0.033$ \\
\hline
\end{tabular}

${ }^{\mathrm{z}} \mathrm{l} \mathrm{kg} \cdot \mathrm{ha}^{-1}=0.8922 \mathrm{lb} /$ acre, $1 \mathrm{Mg} \cdot \mathrm{kg}^{-1}=0.5 \mathrm{ton} / \mathrm{lb}$.

NUE, especially in the case of limiting or overabundant N supply. Particularly, high fertigation frequency increases the recovery of fertilizer- $\mathrm{N}$ by the crop. Moreover, considering that fertigation allows in-season adjustment of the $\mathrm{N}$ rate and timing of $\mathrm{N}$ delivery, it should be managed to maintain the crop at optimal $\mathrm{N}$ nutritional status during the whole growth cycle. The optimal $\mathrm{N}$ status of any crop in any situation is defined by species-specific curves of critical $\mathrm{N}$ concentration. These curves should be the reference to calibrate 
quick tests, like chlorophyll meter readings and measurements of $\mathrm{NO}_{3}-\mathrm{N}$ concentration in petiole sap, which represent essential tools to guide dynamic fertilization management.

\section{Literature cited}

Agostini, F., F. Tei. M. Silgram, M. Farneselli, P. Benincasa, and M.F. Aller. 2010. Decreasing $\mathrm{N}$ leaching in vegetable crops through improvements in $\mathrm{N}$ fertiliser management, p. 147-200. In: E. Lichtfouse (ed.). Genetic engineering, biofertilisation, soil quality and organic farming. Sustainable Agr. Rev. Vol. 4. Springer, Dordrecht, The Netherlands.

Battilani, A., P. Bussieres, and Y. Dumas. 2003. FERTIRRIGERE: A simple toolmodel for managing water and nutrient supply in drip-irrigated processing tomatoes. Acta Hort. 613:155-158.

Benincasa, P., A. Boldrini, F. Tei, and M. Guiducci. 2004. N release from several green manure crops. Proc. VIII European Soc. Agron. Congr.-Addendum, Copenhagen, Denmark, 11-15 July 2004, p. 971-972.

Benincasa, P., C. Beccafichi, M. Guiducci, and F. Tei. 2006. Source-sink relationship in processing tomato as affected by fruit load and nitrogen availability. Acta Hort. 700:63-66.

Benincasa, P., G. Tosti, A. Boldrini, F. Tei, and M. Guiducci. 2008. Poliannual results on soil $\mathrm{N}$ management and maize $\mathrm{N}$ nutrition by green manuring p. 194198. In: D. Neuhoff, N. Halberg, T. Alföldi, W. Lockeretz, A. Thommen, I.A. Rasmussen, J. Hermansen, M. Vaarst, L. Lueck, F. Caporali, H.H. Jensen, P. Migliorini, and H. Willer (eds.). Cultivating the future based on science, Vol. 1: Organic crop production. Proc. II Intl. Soc. Organic Agr. Res. Congr., Modena, Italy, 18-20 June 2008.

Benincasa, P., M. Guiducci, and F. Tei. 2007. Mineral N fertigation versus organic fertilisation in processing tomato. Proc. XVI Intl. Sci. Ctr. Fert. Congr. Gent, Belgium. 16-19 Sept. 2007 p. 76-81.

Boldrini, A., P. Benincasa, G. Tosti, F. Tei, and M. Guiducci. 2007. Apparent N balance in organic and conventional low input cropping system. Proc. Quality Low Input Food Mtg. Hohenheim, Germany, 20-23 Mar. 2007, p. 264-267.

Burns, I.G. 2006. Assessing N fertiliser requirements and the reliability of different recommendation systems. Acta Hort. 700:35-48.

Caloin, M. and O. Yu. 1984. Analysis of the time course of change in nitrogen content in
Dactylis glomerata L. using a model of plant growth. Ann. Bot. (Lond.) 54:69-76.

Chen, S.K., C.A. Edwards, and S. Subler. 2003. The influence of two agricultural biostimulants on nitrogen transformations, microbial activity, and plant growth in soil microcosms. Soil Biol. Biochem. $35: 9-19$.

Farneselli, M. 2008. Improving fertigation management in processing tomato. University of Perugia, Perugia, Italy, PhD Diss.

Farneselli, M., G. Tosti, P. Benincasa, M. Guiducci, and F. Tei. 2009. Potential N leaching under several fertilisation strategies in processing tomato. Proc. 16th $\mathrm{N}$ Wkshp., Torino, Italy, 28 June-1 July 2009 , in press.

Farneselli, M., P. Benincasa, and F. Tei. 2010. Validation of $\mathrm{N}$ nutritional status tools for processing tomato. Acta Hort. 852:227-232.

Fink, M. and H.C. Scharpf. 2000. Apparent nitrogen mineralization and recovery of nitrogen supply in field trials with vegetable crops. J. Hort. Sci. Biotechnol. 75:723-726.

Gadagi, R.S., P.U. Krishnaraj, J.H. Kulkarni, and T. Sa. 2004. The effect of combined Azospirillum inoculation and nitrogen fertilizer on plant growth promotion and yield response of the blanket flower Gaillardia pulchella. Sci. Hort. 100:323332.

Gianquinto, G., P. Sambo, and A. Bona. 2003. The use of SPAD-502 chlorophyll meter for dynamically optimising the nitrogen supply in potato crop: A methodological approach. Acta Hort. 627:217-224.

Good, A.G., A.K. Shrawat, and D.G. Muench. 2004. Can less yield more? Is reducing nutrient input into the environment compatible with maintaining crop production? Trends Plant Sci. 9:597-605.

Greenwood, D.J., G. Lemaire, G. Gosse, P. Cruz, A. Draycott, and J.J. Neeteson. 1990. Decline in percentage N of C3 and $\mathrm{C} 4$ crops with increasing plant mass. Ann. Bot. (Lond.) 66:425-436.

Greenwood, D.J., K. Kubo, I.G. Burns, and A. Draycott. 1989. Apparent recovery of fertilizer $\mathrm{N}$ by vegetable crops. Soil Sci. Plant Nutr. 35:367-381.

Guo, R.Y., C. Nendel, C.R. Rahn, C.G. Jiang, and Q. Chen. 2010. Tracking nitrogen losses in a greenhouse crop rotation experiment in North China using the EU-Rotate_N simulation model. Environ. Pollut. 158:2218-2229.

Hirel, B., J. Le Gouis, B. Ney, and A. Gallais. 2007. The challenge of improving nitrogen use efficiency in crop plants:
Towards a more central role for genetic variability and quantitative genetics within integrated approaches. J. Expt. Bot. 58:2369-2387.

Home, P.G., R.K. Panda, and S. Kar. 2002. Effect of method and scheduling of irrigation on water and nitrogen use efficiencies of Okra (Abelmoschus esculentus). Agr. Water Mgt. 55:159-170.

Janssen, B.H. 1998. Efficient use of nutrients: An art of balancing. Field Crops Res. 56:197-201.

Jimenez, S., J.I. Ales, M.T. Lao, B. Plaza, and M. Perez. 2006. Evaluation of nitrate quick tests to improve fertigation management. Commun. Soil Sci. Plant Anal. 37:2461-2469.

Lemaire, G. 2007. Diagnostic tool(s) for plant and crop $\mathrm{N}$ status. Theory and practice for crop $\mathrm{N}$ management. Proc. XV N Wkshp., Lleida, Spain, 28-30 May 2007, p. 15-29.

Lemaire, G. and F. Gastal. 1997. N uptake and distribution in plant canopies, p. 3-4l. In: G. Lemaire (ed.). Diagnosis of nitrogen status in crops. Springer-Verlag, Berlin, Germany.

Li, Z. 2003. Use of surfactant-modified zeolite as fertilizer carriers to control nitrate release. Microporous Mesoporous Mater. 61:181-188.

Linaje, A., L. Munoz-Guerra, and I. Carrasco. 2005. Evaluation of the use of nitrification inhibitor DMPP on the risk of nitrate leaching in different crop system in Spain. Proc. XIV N Wkshp., Maastricht, The Netherlands, 24-26 Oct. 2005, p. 149152.

Ma, C.H. and T. Kalb. 2006. Development of starter solution technology as a balanced fertilization practice in vegetable production. Acta Hort. 700:173185.

Macdonald, A.J., P.R. Poulton, M.T. Howe, K.W.T. Goulding, and D.S. Powlson. 2005. The use of cover crops in cereal based cropping systems to control nitrate leaching in SE England. Plant Soil 273:355-373.

Maynard, D.N., A.V. Barker, P.L. Minotti, and N.H. Peck. 1976. Nitrate accumulation in vegetables. Adv. Agron. 28:71-117.

Nason, G.E. and D.D. Myrold. 1991. ${ }^{15} \mathrm{~N}$ in soil research: Appropriate application of rate estimation procedures. Agr. Ecosyst. Environ. 34:427-441.

Neeteson, J.J. and O.T. Carton. 2001. The environmental impact of nitrogen in field vegetable production. Acta Hort. 563:21-28.

Neeteson, J.J., R. Booij, and A.P. Whitmore. 1999. A review on sustainable nitrogen 
management in intensive vegetable production systems. Acta Hort. 506:17-26.

Nendel, C., U. Schmutz, A. Venezia, F. Piro, and C.R. Rahn. 2009. Converting simulated total dry matter to fresh marketable yield for field vegetables at a range of nitrogen supply levels. Plant Soil 325: 319-334.

Osborne, S.L. 2006. Starter nitrogen fertilizer impact on soybean yield and quality in the northern Great Plains. Agron. J. 98:1569-1574.

Petersen, J., B. Hansen, and P. Sørensen. 2004. Nitrification of ${ }^{15} \mathrm{~N}$-ammonium sulphate and crop recovery of ${ }^{15} \mathrm{~N}$-labelled ammonium nitrates injected in bands. Eur. J. Agron. 21:81-92.

Rahn, C. 2002. Management strategies to reduce nutrient losses from vegetables crops. Acta Hort. 571:19-25.

Rather, K. and M. Schenk. 2005. Nitrogen and curd compactness of cauliflower (Brassica oleracea var. botrytis) F-1-hybrid. European J. Hort. Sci. 70:60-66.

Remie, B., K. Groenwold, J. Rovres, O. Clevering, H. Pijnenburg, M. Hekkert, and H. Lagenveld. 2003. Nutrient management on vegetables farms: What will be the future? Acta Hort. 627:275-282.

Schenk, M.K. 2006. Nutrient efficiency of vegetable crops. Acta Hort. 700:25-38.

Shapiro, C.A. and C.S. Wortmann. 2006. Corn response to nitrogen rate, row spacing, and plant density in eastern Nebraska. Agron. J. 98:529-535.

Singandhupe, R.B., G.G.S.N. Rao, N.G. Patil, and P.S. Brahmanand. 2003. Fertigation studies and irrigation scheduling in drip irrigation system in tomato crop
(Lycopersicon esculentum L.). Eur. J. Agron. 19:327-340.

Tei, F., A. Onofri, and M. Guiducci. 1996. Relationship between $\mathrm{N}$-concentration and growth in sweet pepper. Proc. IV European Soc. Agron. Congr., p. 602603.

Tei, F., P. Benincasa, and M. Guiducci. 1999. Nitrogen fertilisation on lettuce, processing tomato and sweet pepper: Yield, nitrogen uptake and the risk of nitrate leaching. Acta Hort. 506:61-67.

Tei, F., P. Benincasa, and M. Guiducci. 2000. Effect of nitrogen availability on growth and nitrogen uptake in lettuce. Acta Hort. 533:385-392.

Tei, F., P. Benincasa, and M. Guiducci. 2002a. Critical nitrogen concentration in processing tomato. Eur. J. Agron. 18:4555.

Tei, F., P. Benincasa, and M. Guiducci. 2002 b. Effect of $\mathrm{N}$ availability on growth, $\mathrm{N}$ uptake, light interception and photosynthetic activity in processing tomato. Acta Hort. 571:209-213.

Tei, F., P. Benincasa, and M. Guiducci. 2003. Critical nitrogen concentration in lettuce. Acta Hort. 627:187-194.

Thorup-Kristensen, K. J. Magid, and S.L. Jensen. 2003. Catch crops and green manures as biological tools in nitrogen management in temperate zones. Adv. Agron. 79:227-302.

Thorup-Kristensen, K. and J.N. Sørensen. 1999. Soil nitrogen depletion by vegetable crops with variable root growth. Acta Agriculturae Scandinavica, sect. B - SoilPlant Sci. 49:92-97.
Thorup-Kristensen, K. and R. Van der Boogard. 1999. Vertical and horizontal development of the root system of carrots following green manure. Plant Soil 212:145-153.

Tosti, G. 2008. Green manure and nitrogen fertility management in organic farming systems. University of Perugia, Perugia, Italy, PhD Diss.

Tosti, G., A. Boldrini, P. Benincasa, F. Tei, and M. Guiducci. 2008. The N nutritional status of processing tomato grown after green manures. Proc. XEuropean Soc. Agron. Congr., Bologna, Italy, 15-18 Sept. 2008, p. 275-276.

Tremblay, N. and C. Belec. 2005. Strategies for environmental responsible $\mathrm{N}$ management using state of the art crop sensing tools. Proc. XIV N Wkshp, p. 279-281.

Van Eerd, L.L. 2007. Assessing different nitrogen use efficiency indices using fieldgrown green bell peppers. Can. J. Plant Sci. 87:565-569.

Vouillot, M.O. and F. Devienne-Barrett. 1999. Accumulation and remobilization of nitrogen in a vegetative winter wheat crop during or following nitrogen deficiency. Ann. Bot. (Lond.) 83:569-575.

Yong-Zhan, M., C.T. MacKown, and D.A. Van Sanford. 1996. Differential effects of partial spikelet removal and defoliation on kernel growth and assimilate partitioning among wheat cultivars. Field Crops Res. 47:201-209.

Zvomuya, F. and C.J. Rosen. 2002. Biomass partitioning and nitrogen use efficiency of 'Superior' potato following genetic transformation for resistance to colorado potato beetle. J. Amer. Soc. Hort. Sci. 127:703-709. 